\title{
PREDIKSI RATA-RATA HARGA BERAS YANG DIJUAL OLEH PEDAGANG BESAR (GROSIR) MENGGUNAKAN METODE ARIMA BOX JENKINS
}

\author{
Aliffia Rahma Anandyani*, Dini Krisnawati Alfiki Astutik, \\ Ni'matul Bariroh, Artanti Indrasetianigsih \\ Program Studi Statistika \\ Fakultas Sains dan Teknologi Universitas PGRI Adi Buana \\ Jl. Dukuh Menanggal XII, Surabaya, Jawa Timur. 60234 \\ *E-mail: aliffiara97@gmail.com
}

\begin{abstract}
Abstrak: Nasi merupakan salah satu makanan masyarakat Indonesia sejak zaman nenek moyang sampai sekarang yang dijadikan sebagai sumber utama karbohidrat dan disajikan dengan lauk pauk untuk melengkapi selera dan kebutuhan gizi seseorang. Padi merupakan salah satu kelompok tanaman pangan yang termasuk dalam sektor Pertanian, Perikanan dan Perkebunan yang menjadi penyumbang Produk Domestik Bruto (PDB) terbesar kedua pada triwulan II-2020, dengan kontribusi sebesar 15,46\% (BPS, 2020). Namun hal ini tentunya tidak terlepas dari permasalahan salah satunya adalah tingginya harga jual oleh pedagang grosir, sehingga merugikan masyarakat terutama bagi masyarakat yang kondisi ekonominya kurang mampu. Sehingga pada penelitian ini akan digunakan metode ARIMA untuk memprediksi harga rata-rata beras yang dijual oleh pedagang besar atau grosir pada periode yang akan datang. Data yang digunakan adalah rata-rata harga beras/kg pada tingkat pedagang besar dari Januari 2010 sampai Juli 2020 untuk memprediksi harga rata-rata beras/kg dalam 12 bulan ke depan. Model yang dipilih adalah ARIMA ([1,11], 1,0). dengan nilai RMSE sebesar 136,63 dan MAPE sebesar 0,87.
\end{abstract}

Kata Kunci: ARIMA, harga rata-rata beras, pedagang besar

\section{PENDAHULUAN}

$\mathrm{S}$ alah satu komoditas hasil pertanian adalah beras. Posisi beras sebagai kebutuhan pokok bagi sebagian besar masyarakat Indonesia, sampai saat ini masih belum dapat tergantikan (Suryana et al., 2009). Total konsumsi beras nasional pada tahun 2017 mencapai 29,13 juta ton atau sekitar 111,58 kilogram per kapita per tahun (BPS, 2017). Mengingat pentingnya beras bagi masyarakata, maka perlu adanya target demi tercapainya kebutuhan pangan yang melingkupi kecukupan produksi beras nasional, pendistribusiannya serta harga yang terjangkau dan aman dikonsumsi bagi setiap warga untuk menopang aktivitasnya sehari-hari sepanjang waktu sangat penting sebagai salah satu faktor yang mempengaruhi terwujudnya ketahanan pangan nasional (Marjuki, 2008).

Sebagai upaya mewujudkan ketahanan pangan maka pemerintah membentuk Kebijakan Pembangunan Pertanian Nasional yang dituangkan dalam Rencana Strategis Kementerian Pertanian Tahun 2010-2014, diarahkan untuk mencapai empat target sukses, yaitu: (1) Pencapaian swasembada untuk komoditas kedelai, daging, gula dan swasembada berkelanjutan untuk komoditas beras dan jagung; (2) Peningkatan 
diversifikasi pangan; (3) Peningkatan nilai tambah, daya saing, dan ekspor, (4) Peningkatan kesejahteraan petani. Telah disadari bahwa untuk mencapai program tersebut, tidaklah mudah karena masih terdapat beberapa permasalahan mendasar untuk pembangunan pertanian dan peningkatan ketahanan pangan (Kementerian Perdagangan, 2013). Beras merupakan komoditas strategis yang dominan dalam ekonomi Indonesia karena berkaitan erat dengan kebijakan moneter dan menyangkut masalah sosial politik (Adiratma, 2004). Perlu adanya kehati-hatian dalam menentukan harganya, kenaikan harga beras akan meningkatkan kesejahteraan petani, namun jika harga beras meningkat maka penduduk miskin juga meningkat. Keunikan yang lain meskipun pemerintah telah menaikkan harga dasar penjualan padi tetap saja petani akan miskin (Machmud, 2005).

Panjangnya rantai distribusi beras menyebabkan harga beras tinggi dan merugikan beberapa pihak seperti petani dan pedagang eceran. Titik pertama adalah saat petani akan menjual beras yang sudah dipanen kepada tengkulak atau pemotong padi, yang akan mengeringkan padi dan menjualnya kepada pemilik penggilingan. Setelah padi digiling menjadi beras, pemilik penggilingan akan menjual beras tersebut ke pedagang grosir berskala besar yang memiliki gudang penyimpanan. Kemudian pedagang grosir berskala besar ini akan kembali menjual beras tersebut kepada pedagang grosir berskala kecil di tingkat provinsi atau kepada pedagang grosir antar pulau (Sihombing, 2018).

Harga beras yang dijual oleh pedagang besar akan berdampak bagi masyarakat, maka dari itu diperlukan prediksi harga pada periode berikutnya sebagai upaya menjaga stabilitas rata-rata harga beras di pedagang besar atau grosir. Peramalan merupakan salah satu metode yang dapat memprediksi suatu nilai pada masa yang akan datang. Pada analisis ini ARIMA Box-Jenkins digunakan untuk memprediksi rata-rata harga beras yang dijual oleh pedagang besar atau grosir pada 12 bulan yang akan datang sebagai upaya stabilisasi harga kebutuhan pangan masyarakat.

\section{METODE PENELITIAN}

Model ARIMA yang dikenalkan oleh Box dan Jenkins dengan $\mathrm{p}$ sebagai orde operator AR, d merupakan orde differencing, dan q orde sebagai operator MA. Asumsi dasar yang harus dipenuhi dalam pemodelan ARIMA yaitu kestationeran data. Untuk mengatasi data yang tidak stasioner dalam varians dilakukan dengan transformasi. Transformasi yang umum digunakan adalah transformasi Box-Cox yang ditunjukkan pada persamaan berikut (Wei, 2006).

$$
T\left(Z_{t}\right)=\frac{Z_{t}^{\lambda}-1}{\lambda}
$$

Kestasioneran data dalam mean secara visual dapat dilihat jika ACF menunjukkan pola yang turun lambat berarti data belum stasioner dalam mean sebaliknya jika pola ACF turun secara cepat, maka data sudah stasioner dalam mean. Data yang tidak stasioner dalam mean diatasi dengan melakukan pembedaan atau differencing. Bentuk persamaan untuk model ARIMA adalah sebagai berikut:

$$
\Phi_{P}\left(B^{s}\right) \phi_{p}(B)(1-B)^{d}\left(1-B^{s}\right)^{D} Z_{t}=\theta_{q(B)} \Theta_{Q}\left(B^{s}\right) a_{t}
$$

Keterangan :

$$
\begin{array}{ll}
\phi_{p} & : \text { parameter autoregresif orde } p \\
\theta_{q} & : \text { parameter moving average orde } q \\
B & : \text { operator backward }
\end{array}
$$




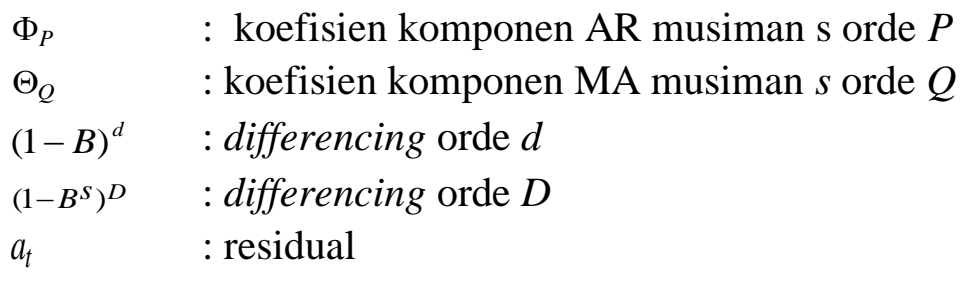

Setelah pendugaan model maka analisis selanjutnya adalah pengujian parameter, untuk mengetahui parameter model signifikan atau tidak. Berikut merupakan hipotesis dan statistik uji dari pengujian signfikansi

$\mathrm{H}_{0}: \beta=0$ (parameter dalam model tidak signifikan)

$\mathrm{H}_{1}: \beta \neq 0$ (parameter dalam model signifikan)

Statistik uji:

$$
t_{\text {hitung }}=\frac{\hat{\beta}}{s e(\hat{\beta})}
$$

dimana:

$\beta$ merupakan parameter dalam model ( $\phi$ atau $\theta$ atau $\Phi$ atau $\Theta$ ). Daerah penolakan: Jika $\left|t_{\text {hitung }}\right|>t_{\alpha / 2, d f}$ maka $\mathrm{H}_{0}$ ditolak (Cryer dan Chan, 2008).

Asumsi residual yang harus dipenuhi dalam ARIMA yaitu residual white noise dan sumsi berdistribusi normal. Pengujian asumsi residual white noise bertujuan mengetahui varians residual bernilai konstan atau tidak (Wei, 2006). Berikut hipotesis, statistik uji dan daerah penolakan dijabarkan sebagai berikut.

$\mathrm{H}_{0}: \rho_{1}=\rho_{2}=\rho_{3}=\cdots=\rho_{k}=0$ (memenuhi asumsi residual white noise)

$\mathrm{H}_{1}$ : minimal terdapat satu $\rho_{k} \neq 0$ (tidak memenuhi asumsi residual white noise)

Statistik uji:

$$
Q=n(n+2) \sum_{k=1}^{K} \frac{1}{(n-k)} \hat{\rho}_{k}^{2}
$$

Dearah penolakan pada pengujian Ljung-Box, jika $Q>\chi_{(1-\alpha),(K-p-q)}^{2}$ maka $\mathrm{H}_{0}$ ditolak dimana nilai $p$ dan $q$ merupakan orde AR dan MA.

Pengujian residual menggunakan uji keselarasan sampel tunggal Kolmogorov Smirnov bertujuan mengetahui residual telah berdistribusi normal atau tidak. Hipotesis yang digunakan untuk uji Kolmogorov Smirnov adalah sebagai berikut (Daniel, 2000).

$H_{0}: F_{n}\left(a_{t}\right)=F_{0}\left(a_{t}\right)$ (Residual berdistribusi normal)

$H_{1}: F_{n}\left(a_{t}\right) \neq F_{0}\left(a_{t}\right)$ (Residual tidak berdistribusi normal)

Statistik uji:

$$
D=\operatorname{Sup}_{a_{t}}\left|F_{n}\left(a_{t}\right)-F_{0}\left(a_{t}\right)\right|
$$

dimana:

$F_{n}\left(a_{t}\right) \quad$ : nilai peluang kumulatif distribusi yang belum diketahui

$F_{0}\left(a_{t}\right) \quad$ : nilai peluang kumulatif dari distribusi normal 
$S\left(a_{t}\right) \quad$ : fungsi peluang komulatif yang dihitung dari data sampel

$\operatorname{Sup}\left(a_{t}\right)$ : nilai supremum atau nilai maksimum dari $\left|S\left(a_{t}\right)-F_{0}\left(a_{t}\right)\right|$.

Daerah penolakan pada pengujian Kolmogorov Smirnov, jika $D>D_{(1-\alpha), n}$ maka $\mathrm{H}_{0}$ ditolak. Pada penelitian ini pemilihan model terbaik menggunakan RMSE dan MAPE. RMSE digunakan dengan tujuan supaya satuan pengukuran data tidak berubah, dapat dihitung dengan rumus pada persamaan berikut (Gooijer \& Hyndman, 2006). Menurut Lee \& Suhartono (2010), rumus RMSE adalah sebagai berikut:

$$
R M S E=\sqrt{\frac{1}{n} \sum_{t=1}^{n}\left(Z_{t}-\hat{Z}_{t}\right)^{2}}
$$

Apabila nilai MAPE yang dihasilkan berada dibawah $10 \%$ artinya model memiliki kinerja sangat bagus, apabila nilai diantara $10 \%$ dan $20 \%$ artinya model memiliki kinerja bagus, apabila nilai diantara $20 \%$ hingga $50 \%$ artinya kinerjanya cukup bagus dan jika nilai diatas 50\% memiliki kinerja buruk (Chang et al., 2007). Rumus MAPE dapat dituliskan pada Persamaan berikut (Gooijer \& Hyndman, 2006).

$$
M A P E=\frac{1}{n} \sum_{t=1}^{n}\left|\frac{Z_{t}-\hat{Z}_{t}}{Z_{t}}\right| \times 100 \%
$$

dimana :

n : banyaknya observasi

$Z_{t} \quad$ : nilai aktual pada waktu ke- $t$

$\hat{Z}_{t} \quad$ : nilai ramalan pada waktu ke- $t$

Sumber data diperoleh dari Badan Pusat Statistika dengan variabel adalah data ratarata bulanan harga beras $/ \mathrm{kg}$ pada tingkat perdagangan besar (grosir) di Indonesia mulai bulan Januari 2010 sampai dengan Juli 2020 dengan satuan Rupiah. Langkah-langkah analisis yaitu sebagai berikut:

1. Mendeksripsikan karakteristik data;

2. Data dibagi menjadi in-sample dan out-sample. Data in-sample digunakan untuk pemodelan, sedangkan data out-sample digunakan untuk validasi hasil peramalan. Data in-sample yang digunakan mulai dari Januari 2010 sampai Juli 2019, sedangkan data out-sample yang digunakan mulai Agustus 2019 sampai Juli 2020;

3. Mengidentifikasikan kestasioneran dalam varians dan mean;

4. Mengidentifikasi model dugaan sementara dengan melihat plot ACF dan PACF;

5. Melakukan pengujian signifikansi parameter model;

6. Melakukan pengujian asumsi residual white-noise dan pengujian asumsi residual berdistribusi normal;

7. Jika model yang didapatkan lebih dari satu, maka pemilihan model terbaik menggunakan nilai RMSE dan MAPE terkecil;

8. Melakukan peramalan rata-rata harga beras untuk memprediksi harga beras tingkat perdagangan besar (grosir) di Indonesia Bulan Agustus 2020 sampai Juli 2021. 


\section{HASIL DAN PEMBAHASAN}

A. Karakteristik Data Rata-Rata Harga Beras Tingkat Pedagang Besar atau Grosir di Indonesia

Analisis statistika deskriptif digunakan untuk mengetahui karakteristik data dari data rata-rata harga beras tingkat perdagangan besar (grosir) di Indonesia mulai Januari 2010 sampai Juli 2020 yang disajikan pada Tabel 1.

Tabel1.Karakteristik rata-rata harga beras tingkat perdagangan besar (grosir) di Indonesia

\begin{tabular}{|c|c|c|c|c|}
\hline Tahun & Rata-Rata & Varians & Minimum & Maximum \\
\hline 2010 & Rp 7,084 & 102,755 & Rp 6,702 & $\operatorname{Rp} \quad 7,617$ \\
\hline 2011 & 7,890 & 271,294 & $\mathrm{Rp} \quad 7,199$ & 8,726 \\
\hline 2012 & 8,642 & 5,053 & 8,537 & 8,778 \\
\hline 2013 & 8,941 & 36,316 & 8,681 & $\mathrm{Rp} \quad 9,262$ \\
\hline 2014 & Rp $\quad 9,638$ & 73,738 & $\operatorname{Rp} \quad 9,414$ & $\operatorname{Rp} 10,344$ \\
\hline 2015 & $\mathrm{Rp} 10,915$ & 89,900 & $\mathrm{Rp} 10,569$ & $\operatorname{Rp} 11,465$ \\
\hline 2016 & $\mathrm{Rp} 11,511$ & 10,630 & $\operatorname{Rp} 11,417$ & $\mathrm{Rp} 11,729$ \\
\hline 2017 & $\operatorname{Rp} 11,535$ & 14,260 & $\operatorname{Rp} 11,411$ & $\operatorname{Rp} 11,838$ \\
\hline 2018 & $\mathrm{Rp} 12,055$ & 32,330 & $\mathrm{Rp} 11,899$ & Rp12,414 \\
\hline 2019 & Rp12,091 & 6,632 & $\mathrm{Rp} 12,008$ & $\mathrm{Rp} 12,222$ \\
\hline
\end{tabular}

Keterangan: Tanda cetak tebal merupakan angka yang dijelaskan.

Tabel 1 menunjukkan harga beras di perdagangan besar (grosir) dari tahun ke tahun mengalami peningkatan terbukti pada tahun 2010, rata-rata tahunan harga beras yaitu sebesar Rp.7.084,2 dan pada tahun 2019 menjadi Rp12.091. Nilai rata-rata harga bulanan beras terendah terjadi pada Januari 2010 yaitu sebesar Rp. 6.702 sedangkan rata-rata bulanan harga beras tertinggi yaitu pada Februari 2018 yaitu sebesar Rp. 12.414. Varians terbesar yaitu ada pada tahun 2011, hal ini menunjukkan bahwa pada tahun tersebut sebaran rata-rata bulanan harga beras tingkat perdagangan besar (grosir) di Indonesia sangat besar. Hal ini diperkuat dengan tampilan secara visual yang disajikan pada Gambar 1 sebagai berikut.

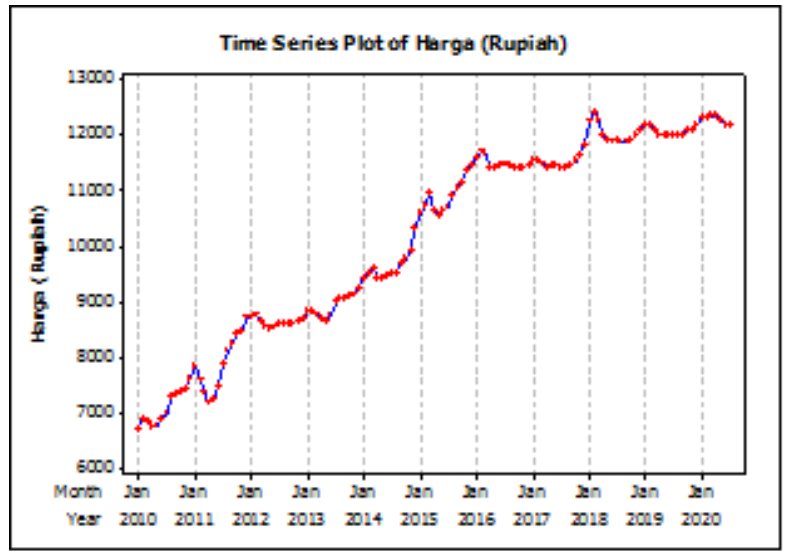

Gambar 1. Time series plot rata-rata harga beras tingkat perdagangan besar (grosir) di Indonesia januari 2010-juli 2020

Gambar 1 menunjukkan rata-rata harga beras tingkat perdagangan besar (grosir) di Indonesia cenderung naik dan berfluktuasi dengan kenaikan harga yang terjadi cukup tinggi pada awal tahun. Kenaikan harga tertinggi dapat dilihat sepanjang tahun 2011 dan sepanjang tahun 2014-2015. Pada tahun 2011 kenaikan harga beras ini disebabkan Pertama, permintaan beras yang tinggi. Kedua, siklus musiman karena berakhirnya panen di beberapa sentra produksi. Ketiga, minimnya pertumbuhan produksi angka ramalan 
(Aram) II yang hanya naik 2,40\% (Rafie dan Fitrie, 2011). Pada tahun 2015, Peningkatan harga beras pada awal tahun 2015 disebabkan adanya peningkatan signifikan pada bulan Februari secara signifikan hanya terjadi dibeberapa kota besar, terutama di pasar grosir beras di Jakarta, yaitu Pasar Induk Beras Cipinang (PIBC). Sementara itu pada waktu yang sama kenaikan harga beras di tingkat konsumen di 82 kota besar rata-rata kurang dari 3\%. Penyabab lainnya adalah stok beras yang dikuasai BULOG menipis, respon pelaku pasar atas menipisnya cadangan beras, penyaluran beras bersubsidi dari program Raskin sejak November 2014 sampai Februari 2015 tersendat, terbentuk persepsi pelaku pasar dan masyarakat akan kekurangan (sortage) penyediaan beras saat paceklik karena pemerintah menyatakan tidak akan melakukan melakukan impor beras (Pusat Sosial Ekonomi dan Kebijakan Pertanian, 2015)

B. Pemodelan ARIMA pada Rata-Rata Harga Beras Tingkat Pedagang Besar atau Grosir di Indonesia

Langkah pertama yang dilakukan adalah pemeriksaan kestasioneran dalam varians dan mean menggunakan data in sample. Untuk melihat kestasioneran data dalam varians menggunakan Box-Cox berikut ini.

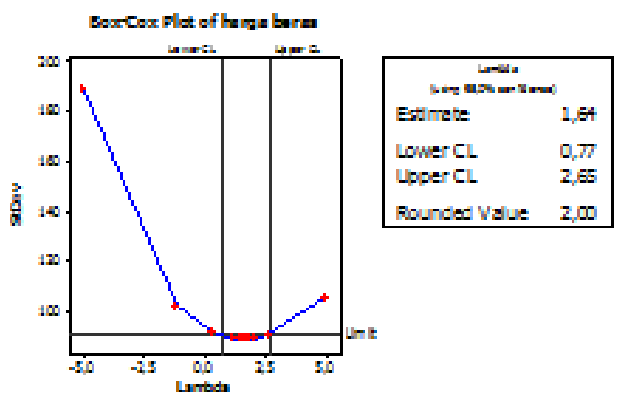

Gambar 2. Box-Cox data In-Sample rata-rata harga beras tingkat perdagangan besar (grosir) di Indonesia

Gambar 2 menunjukkan bahwa data rata-rata harga beras grosir dengan menggunakan data in-sample mulai tahun 2010 sampai tahun 2019 diperoleh nilai rounded value $\lambda$ sebesar 2,00. Nilai estimasi tersebut sama dengan 1,64 serta pada nilai Lower Cofidence Limit (LCL) dan Upper Cofidance Limit (UCL) sudah memuat nilai 1 (satu), sehingga dapat disimpulkan bahwa data harga beras stasioner dalam varians. Selanjutnya akan dilakukan pemeriksaan kestationeran data dalam mean yang disajikan pada gambar berikut.

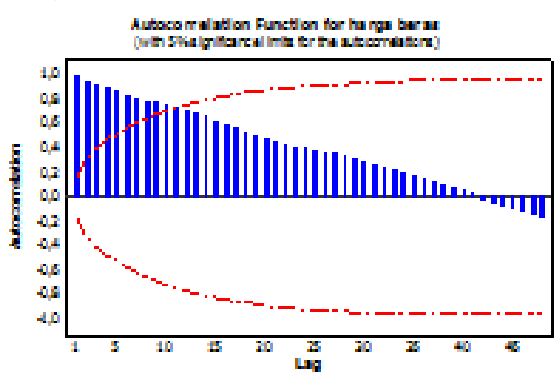

(a)

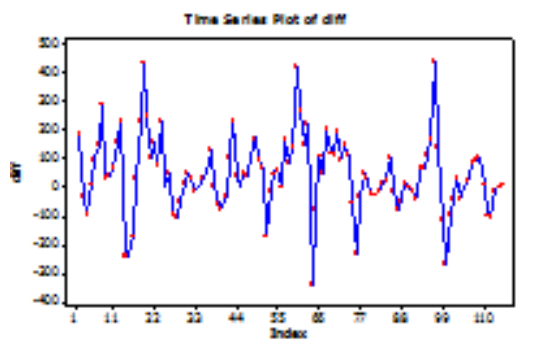

(b)

Gambar 3. (a) Plot ACF rata-rata harga beras grosir dan (b) Time series Plot Setelah Differencing

Gambar 3 (a) menunjukkan data belum stationer dalam mean karena lag pada ACF (Autocorrelation Function) memiliki pola menurun lambat sehingga diperlukan differencing sebanyak satu kali untuk mengatasi ketidakstationeran data. Hasil data yang 
telah di differencing disajikan pada Gambar (b) yang memberikan informasi data differencing sudah berfluktuasi pada nilai yang berada dalam secara konstan, sehingga dapat dikatakan dengan differencing sebanyak satu kali data telah stasioner dalam mean. Tahap selanjutnya adalah identifikasi model dugaan dengan melihat plot ACF dan PACF menggunakan data in sample yang ditunjukkan pada Gambar 4.

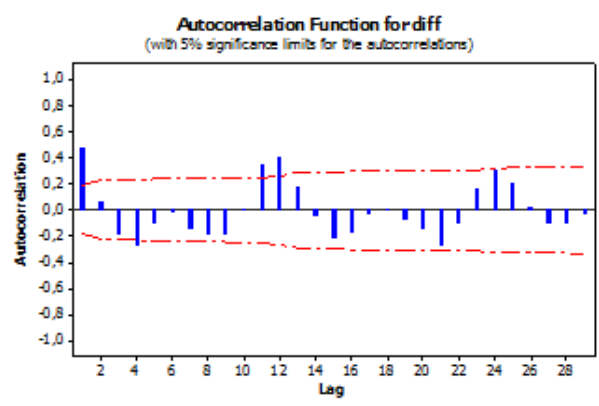

(a)

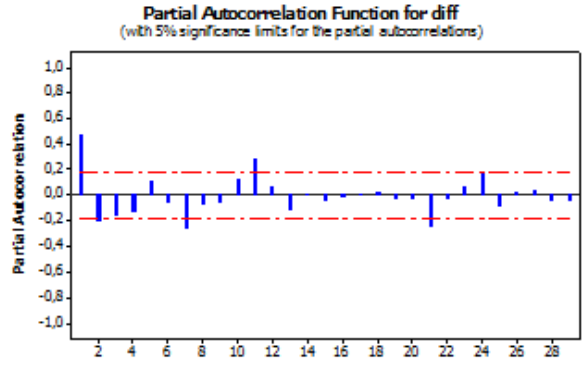

(b)

Gambar 4. (a) Plot ACF dan (b) Plot PACF Data Differencing

Gambar 4 menunjukkan plot ACF (a) terlihat lag signifikan yaitu 1, 4, 11 dan 12 yang digunakan menduga model MA (Moving Average) sedangkan plot PACF (b) signifikan pada lag 1, 2, 7, 11 dan 21 digunakan menduga model AR (Autoregressive). Estimasi pengujian signifikansi parameter parameter AR pada MA pada masing-masing dugaan model ARIMA ditunjukkan Tabel 2.

Tabel 2. Estimasi dan pengujian signifikansi parameter model dugaan ARIMA

\begin{tabular}{cccccc}
\hline Model Dugaan & Parameter & Estimasi & $\mid$ thitung $\mid$ & $t_{(\alpha / 2 ; n-p)}$ & $\boldsymbol{P}$-Value \\
\hline ARIMA ([1,11,21],1,0) & $\phi_{1}$ & 0,4781 & 6,71 & 2,2722 & $<0,0001^{*}$ \\
& $\phi_{11}$ & 0,3892 & 5,38 & 2,2722 & $<0,0001^{*}$ \\
ARIMA ([1,11],1,0) & $\phi_{21}$ & $-0,2105$ & $-2,68$ & 2,2722 & $0,0086^{*}$ \\
ARIMA (0,1,[1,11,12]) & $\phi_{1}$ & 0,4854 & 6,64 & 2,2719 & $<0,0001^{*}$ \\
& $\phi_{11}$ & 0,3686 & 4,99 & 2,2719 & $<0,0001^{*}$ \\
& $\theta_{1}$ & $-0,4397$ & $-5,42$ & 2,2722 & $<0,0001^{*}$ \\
& $\theta_{11}$ & $-0,3536$ & $-4,02$ & 2,2722 & $0,0001^{*}$ \\
& $\theta_{12}$ & $-0,4057$ & $-4,48$ & 2,2722 & $<0,0001^{*}$ \\
\hline
\end{tabular}

Tabel 2 menunjukkan bahwa model dugaan ARIMA memiliki parameter signifikan karena nilai mutlak statistik uji $t_{\text {hitung }}$ pada model lebih besar dari $t_{(\alpha / 2 ; n-p)}$ dan diperkuat dengan $p$-value yang lebih kecil dari taraf signifikan $\alpha$ sebesar 0,05 . Pengujian asumsi residual white noise menggunakan uji L-Jung Box dengan hasil pengujian ditunjukkan pada Tabel 3.

Tabel 3. Pengujian asumsi residual White Noise

\begin{tabular}{cccccc}
\hline Model ARIMA & Lag & $\chi^{2}$ & Df & $\chi^{2}(\alpha ; d f)$ & p-value \\
\hline ARIMA ([1,11,21],1,0) & 6 & 2,67 & 3 & 7,814 & $0,4454^{*}$ \\
& 12 & 4,86 & 9 & 16,918 & $0,8461^{*}$ \\
ARIMA ([1,11],1,0) & 18 & 8,10 & 15 & 24,995 & $0,9197^{*}$ \\
& 24 & 12,44 & 21 & 32,670 & $0,9270^{*}$ \\
& 6 & 5,02 & 4 & 9,4877 & $0,2855^{*}$ \\
& 12 & 7,78 & 10 & 18,307 & $0,6500^{*}$ \\
& 18 & 13,07 & 16 & 26,296 & $0,6673^{*}$
\end{tabular}




$\begin{array}{cccccc} & 24 & 23,00 & 22 & 33,924 & 0,3579^{*} \\ \text { ARIMA }(\mathbf{0 , 1 , [ 1 , 1 1 , 1 2 ] )} & 6 & 5,92 & 3 & 7,814 & 0,1157^{*} \\ & 12 & 8,35 & 9 & 16,918 & 0,4995^{*} \\ & 18 & 11,63 & 15 & 24,995 & 0,7065^{*} \\ & 24 & 21,96 & 21 & 32,670 & 0,4017^{*}\end{array}$

Tabel 3 menunjukkan bahwa hasil pengujian asumsi residual white noise pada ketiga model dugaan telah terpenuhi karena diperoleh statistik uji $\chi^{2}$ lebih kecil dari $\chi_{(\alpha ; d f)}^{2}$ dan diperkuat dengan nilai $p$-value yang lebih besar dari taraf signifikan $\alpha$ sebesar 0,05 . Model yang memenuhi asumsi residual white noise selanjutnya dilakukan pengujian asumsi residual berdistribusi normal dengan menggunakan kolmogorov smirnov dengan hasil pengujian asumsi residual berdistribusi normal ditunjukkan pada Tabel 4.

Tabel 4.Pengujian Asumsi Residual Berdistribusi Normal

\begin{tabular}{cccc}
\hline Model Dugaan & $D_{\text {hitung }}$ & $D_{(1-\alpha / 2 ; n)}$ & Kesimpulan \\
\hline ARIMA $([\mathbf{1 , 1 1 , 2 1 ] , 1 , 0 )}$ & 0,0997 & 0,127 & Residual Berdistribusi Normal \\
ARIMA $([\mathbf{1 , 1 1}], \mathbf{1 , 0})$ & 0,089 & 0,127 & Residual Berdistribusi Normal \\
ARIMA $(\mathbf{0 , 1},[\mathbf{1 , 1 1 , 1 2}])$ & 0,0844 & 0,127 & Residual Berdistribusi Normal \\
\hline
\end{tabular}

Tabel 4 menunjukkan bahwa hasil pengujian asumsi residual berdistribusi normal memberikan keputusan $H_{0}$ gagal ditolak karena diperoleh semua nilai $D_{\text {hitung }}$ atau statistik uji Kolmogorov Smirnov masing-masing model lebih kecil dari $D_{(0.99 ; 114)}$ sebesar 0,127 sehingga menunjukkan bahwa residual model ARIMA ([1,11,21],1,0), ARIMA $([1,11], 1,0)$ dan ARIMA $(0,1,[1,11,12])$ memenuhi asumsi residual berdistribusi nomal. Oleh karena itu ketiga model dapat digunakan untuk tahap pemilihan terbaik untuk mendapatkan satu model yang digunakan untuk meramalkan harga beras tingkat perdagangan besar (grosir) di Indonesia. Hasil pemilihan model terbaik ditunjukan pada Tabel 5.

Tabel 5. Pemilihan model terbaik

\begin{tabular}{ccc}
\hline Model Dugaan & \multicolumn{2}{c}{ Kriteria Out Sample } \\
\cline { 2 - 3 } & RMSE & MAPE \\
\hline ARIMA ([1,11,21],1,0) & 269,39 & 1,65 \\
ARIMA ([1,11],1,0) & $\mathbf{1 3 6 , 6 3}$ & $\mathbf{0 , 8 7}$ \\
ARIMA (0,1,[1,11,12]) & 276,68 & 1,94 \\
\hline
\end{tabular}

Tabel 5 menunjukkan bahwa berdasarkan kriteria out sample,model ARIMA $([1,11], 1,0)$ menghasilkan RMSE dan MAPE nilai terkecil, sehingga dapat dikatakan bahwa model tersebut baik untuk digunakan dalam memprediksi rata-rata harga beras tingkat perdagangan besar atau grosir. Bentukumum model ARIMA $([1,11], 1,0)$ dapat diuraikan menjadi persamaan model berikut

$$
\begin{aligned}
& Z_{t}=\left(1-\phi_{1}\right) Z_{t-1}-\phi_{1} Z_{t-2}+\phi_{11} Z_{t-11}+\phi_{11} Z_{t-12}+a_{t} \\
& Z_{t}=(1-0.4854) Z_{t-1}-0.4854 Z_{t-2}+0.3686 Z_{t-11}+0.3686 Z_{t-12}+a_{t}
\end{aligned}
$$

Berdasarkan model matematis ARIMA $([1,11], 1,0)$ diketahui bahwa harga beras tingkat perdagangan besar (grosir) pada waktu ke $t$ di Indonesia dipengaruhi oleh harga beras tingkat perdagangan besar (grosir) pada 1 bulan, 2 bulan, 11 bulan dan 12 bulan sebelumnya serta dipengaruhi oleh nilai kesalahan peramalan Prediksi rata-rata harga beras dilakukan selama satu tahun kedepan yaitu mulai Agustus 2020 sampai dengan Juli 
2021 dengan menggunakan model terbaik yaitu ARIMA $([1,11], 1,0)$ ditunjukkan pada Tabel 6.

Tabel 6. Hasil peramalan rata-rata harga berastingkat perdagangan besar (grosir) di Indonesia

\begin{tabular}{cccc}
\hline Periode & Batas Bawah & Prediksi & Batas Atas \\
\hline Agu-20 & Rp. $10,779.57$ & Rp. 12,122.84 & Rp. 13,466.11 \\
Sep-20 & Rp. $10,672.62$ & Rp. 12,128.16 & Rp. 13,583.69 \\
Okt-20 & Rp. $10,564.58$ & Rp. 12,144.81 & Rp. 13,725.05 \\
Nov-20 & Rp. $10,463.40$ & Rp. 12,172.37 & Rp. 13,881.33 \\
Des-20 & Rp. $10,373.05$ & Rp. 12,209.46 & Rp. 14,045.88 \\
Jan-21 & Rp. $10,280.57$ & Rp. 12,240.48 & Rp. 14,200.39 \\
Feb-21 & Rp. $10,170.11$ & Rp. 12,248.53 & Rp. 14,326.56 \\
Mar-21 & Rp. $10,043.00$ & Rp. 12,234.78 & Rp. 14,426.56 \\
Apr-21 & Rp. $9,917.82$ & Rp. 12,218.03 & Rp. 14,518.24 \\
Mei-21 & Rp. $9,801.06$ & Rp. 12,205.15 & Rp. 14,609.23 \\
Jun-21 & Rp. $9,694.39$ & Rp. 12,198.22 & Rp. 14,702.04 \\
Jul-21 & Rp. $9,587.70$ & Rp. 12,195.36 & Rp. 14,803.03 \\
\hline
\end{tabular}

Tabel 6 menunjukkan bahwa prediksi rata-rata harga beras tingkat perdagangan besar (grosir) di Indonesia periode Agustus 2020 sampai Juli 2021 berfluktuasi. Harga beras diperkirakan paling rendah terjadi pada bulan Agustus 2020 sebesar Rp 12.122,84 sedangkan pada bulan Februari 2021 merupakan harga paling tinggi sebesar Rp $12.248,53$.

\section{KESIMPULAN}

Berdasarkan analisis dan pembahasan yang telah dilakukan diperoleh kesimpulan diketahui bahwa rata-rata harga beras terendah yaitu pada tahun 2010 sebesar Rp. 6.702 sedangkan tertinggi yaitu pada tahun 2018 sebesar Rp. 12.414.Model terbaik dari prediksi rata-rata harga beras tingkat perdagangan besar (grosir) di Indonesia adalah ARIMA $([1,11], 1,0)$. Peramalan harga berastingkat perdagangan besar (grosir) di Indonesia diperkirakan paling rendah terjadi pada bulan Agustus 2020 sebesar Rp. 12.122,84 sedangkan pada bulan Maret 2021 merupakan harga paling tinggi sebesar Rp. 12.234,78.

\section{DAFTAR PUSTAKA}

Adiratma, E.R. (2004). Stop Tanam Padi?. Memikirkan Kondisi Petani Padi Indonesia dan Upaya Meningkatkan Kesejahteraannya. Jakarta: Penebar Swadaya

Badan Pusat Statistik. (2017). Kajian Konsumsi Bahan Pokok 2017. Jakarta: BPS RI

Badan Pusat Statistik. (2020). Buletin Statistik Bulanan : Indikator Ekonomi. Edisi Juni. Jakarta: BPS RI

Chang, P-C., Wang, Y.-W., \& Liu, C.-H. (2007). The Development of Weighted Evolving Fuzzy Neural Network for PCB Sales Forecasting. Expert Systems with Applications, 32(1), 86-96.

Cryer, J.D., \& Chan, K.S. (2008). Time Series Analysis with Application in R. New York: Springer.

Daniel, W.W. (2000). Applied Nonparametric Statistics (2nd Ed.). Boston: Duxbury Press

Gooijer, J.D., \& Hyndman, R.J. (2006). 25 Years of Time Series Forecasting. International Journal of Forecasting, 22(3), 443-473.

Harianto. (2001). Pendapatan, Harga dan Konsumsi Beras. Dalam Bunga Rampai Ekonomi Beras. Jakarta (ID): Lembaga Penyelidikan Ekonomi Masyarakat. Fakultas Ekonomi. Universitas Indonesia.

Kementerian Perdagangan. (2013). Laporan Akhir Analisis Dinamika Konsumsi Pangan Masyarakat Indonesia. Jakarta: Pusat Kebijakan Perdagangan Dalam Negeri, Badan Pengkajian Dan Pengembangan Kebijakan Perdagangan Kementerian Perdagangan. 
Lee, M.H., \& Suhartono. (2010). A Weighted Fuzzy Time Series for Forecasting Seasonal Data. Second International Conference on Mathematical Sciences, Kuala Lumpur, Malaysia.

Machmud Z. (2005). Faktor-Faktor yang Mempengaruhi Tingkat Suku Bunga di Indonesia. Jurnal Ekonomi dan Bisnis Indonesia, 21(1).

Marjuki, F.A. (2008). Analisis Faktor-Faktor yang Mempengaruhi Harga Beras di Indonesia Tahun 19812006.Surakarta: FE UMS.

Pusat Sosial Ekonomi dan Kebijakan Pertanian. (2015). Melambungnya Harga Beras dan Solusi Penyelesaiannya. https://pse.litbang.pertanian.go.id/ind/pdffiles/anjak_2015_05.pdf. (Diakses pada 12 September 2020).

Rafie, B.T., \& Arifenie, F.N. (2011). Wah, harga beras masih terus menanjak naik. https://nasional.kontan.co.id/news/wah-harga-beras-masih-terus-menanjak-naik-1. (Diakses pada 12 September 2020).

Sihombing, M. (2018). Inilah Jalur Distribusi Beras Hingga Ke Konsumen. https://ekonomi.bisnis.com/read/20180117/99/727664/inilah-jalur-distribusi-beras-hingga-kekonsumen. (Diakses pada 12 September 2020).

Suryana R.N., Rachmina, D., Sumedi., \& Novianti T. (2009). Analisis efisiensi dan daya saing padi pandan wangi Indonesia. Jurnal Pertanian.

Wei, W.W. (2006). Time Series Analysis Univariat and Multivariat Methods. Canada: Addision Wesley Publishing Company. 